\title{
Exploring Habitus and Writer Identities: An ethnographic study of writer identity construction in the FET Phase at two schools in the Western Cape
}

\author{
Michelle Van Heerden \\ University of the Western Cape
}

\section{SETTING, CAST AND PLOT}

Globalisation processes have resulted in increasingly pluralistic societies, a phenomenon with ripple effects in contexts such as universities, which now provide access to heterogeneous student populations with diverse rituals, beliefs, cultures and languages. For this reason, deficit discourses that frame students as underprepared for the demands of tertiary studies are a global phenomenon (Boughey, 2003; Lillis, 2003; Lea \& Street, 1998). Furthermore, the different identities, histories and dispositions (Bourdieu, 1990) of students result in hybrid linguistic repertoires, with some repertoires being more powerful than others (Blommaert, 2001; Blommaert, Collins \&Slembrouck, 2005; Rampton, 2003). Therefore, having access to the preferred linguistic repertoire - in most cases standard English - is an asset, because this repertoire is more closely aligned than others to tertiary education practices and discourses. As a result, the scholarly community can be daunting for many first-year students whose linguistic identities are not always aligned to institutional values, practices and discourses; students can easily be indexed as under-achieving or incompetent.

While there are numerous factors that can affect access, redress and throughput in education, this study focuses on writing because studies over the past decade highlight the inability of many South African learners to succeed at universities. The poor performance of such students is often linked to diverse linguistic repertoires and a lack of adequate preparation in the Further Education and Training (FET) Phase, which is grades 10 to 12 , the grades before entering first-year undergraduate programmes. The goal of this study is thus to illuminate the writer identities constructed in the FET Phase in relation to the national curriculum and exit question papers for English Additional Language (EAL). In doing so, it also seeks to shed light on the intricate links between policy shifts (NCS, 2003; CAPS, 2011) and the nature of the National Senior Certificate examination for language. It considers the implications 
of these elements for strengthening or impeding writer identities in the FET Phase: understanding these intersections enables insights into the mismatches between these writer identities and those required for success at university.

\section{THE COMPLICATION}

South African research on firstyear student experiences has drawn attention to the complex relationship between linguistic repertoires, academic discourses and students' educational and socio-economic backgrounds (Boughey, 2003, 2010). Yet there is little exploration of the kinds of writer identities firstyear students possess when entering the university. Since the core purpose of the FET Phase is 'to provide access to higher education; to facilitate the transition from education to the workplace and to providing employers with a sufficient profile of a learner's competences (CAPS, 2011: 4 ), research into this phase is needed. Moreover, a corresponding gap in the research literature is the development of writing, especially EAL writing, in the final three years of secondary schooling.

This thesis is thus positioned squarely in the gap between secondary schooling and first-year university. Accordingly, I pose the following main research question:

In what ways do writer identities constructed in the FET Phase strengthen or impede academic writing at university?

\section{Sub-questions are:}

- What field effects and institutional factors structure the teaching of writing in the FET Phase? What are teachers' pedagogical moulds in relation to writing?
- What writing practices and genres are encouraged through assessment in the FET Phase?

- How do these practices and genres assist or impede learners' writing in the first year of study in the Faculty of Education?

- What are the implications of the above for constructing sound and enabling writer identities at FET and first-year level?

\section{THE UNDERLYING SCRIPT: IDENTITY MATTERS}

Poststructural understandings see identity as emergent in discourse and therefore bound up with ideologies and power relations, especially in multilingual contexts (Norton; 1997, 2013; Ivaniç, 1998; Bucholtz\& Hall, 2005). Identity is therefore conceived of as complex, multiple, and context-specific. School as a site of socialisation plays a major role in identity construction. Although school literacy practices can develop or shape identities in numerous ways, it appears as if in many state schools in South Africa the writer identities constructed are often not those expected and valued in academic contexts. Writing at schools entails habitual social acts of teaching and assessing writing that moulds situated writer identities. .For this reason, the notion of identities in flux applies to academic writing development: firstyear students are in transition and can experience the new learning site as fluctuating between what was familiar and the new and complex demands of the culture of writing that they are entering. In general, in South Africa schools focus more on writing as a set of competencies to be mastered and less on the '...underlying conditions that make performance possible...' (Pennycook, 
2007: 66) or impede it, such as structural inequalities and material conditions.

However, the specific practices that learners engage in are not similar for everyone across the education spectrum, given the substantial differences reflected in school contexts, socio-economic status and other cultural features such as wellequipped school libraries and science laboratories. School practices are thus powerful conduits of identity formation; they can lead to the recognition of writer identities as poor, mediocre or excellent. The intention of this study is to explore the ways in which situated school writer identities are constructed in two different contexts to lay the basis for understanding how school-valued discourses and practices are differentially valued on the academic market of one higher institution.

\section{REVIEWING THE \\ LITERATURE AND THE COMPANY THAT I KEEP}

To tease out the different factors at play in the South African postcolonial educational field, I draw on Bourdieu's notions of field, habitus and cultural capital (Bourdieu, 1994; Bourdieu \&Passeron, 1990). Even though my interest is in cultural capital in relation to the English writing practices acquired, my thesis will inevitably touch on the ways that socioeconomic conditions, school contexts and proficiency in the 'legitimate language' impact on learners' access to economic capital and how this contributes towards maintaining inequalities in South African contexts. Part of this focus involves an analysis of the ways in which other forms of social and economic capital add weight to apparently similar forms of cultural capital and endow certain writers with greater symbolic capital in the education field. In analysing policy documents, curriculum and assessment concepts, and student texts, I draw on an analytical framework informed by Systemic Functional Linguistics (SFL) (Halliday, 1985). This framework enables an understanding of theoretical underpinnings in the curriculum and assessment activities, sheds light on the text types used, their social purpose and associated language features, and provides a means of capturing the development of writer identities in students' texts by analysing the workings of Halliday's three metafunctions - ideational, interpersonal and textual - in the texts.

The combination of Bourdieu's concepts and Systemic Functional Linguistic (SFL) provided a richer understanding of the construction of writer identities in the FET phase. Both are concerned with opening up ideologies in social contexts and also with the significance of language in constructing power and identities in texts or practices. Additionally, these concepts enabled an understanding of how national policies played out in two different local schools and classrooms. As a result, my thesis explores both the visible and the invisible curriculum, and specifically the power the invisible curriculum (structured by the jostling for control of the field) holds for the construction of writer identities and its implications for academic success at universities.

\section{METHOD: AN \\ ETHNOGRAPHIC FRAMING}

This was an empirical study in a context of continuous curriculum shifts since 1994. Ethnography provided a means of exploring the ways that policy shifts impact on practices in local contexts. Furthermore, ethnography is uniquely 
context-situated in terms of time, place and participants. Thus, focusing on two schools with different linguistic, historical and cultural profiles allows for a deeper understanding of the ways that policy implementation can be influenced by historical, cultural and local, contextual factors. Moreover, ethnography is aimed at demonstrating complexities (Blommaert\& Dong, 2010); the two situated school contexts yield interesting comparative data on the complexities of the construction of writer identity in the FET Phase.

To identify appropriate schools for this study, I first looked at student records at a university in the Western Cape then I selected two feeder schools with different histories, linguistic and socioeconomic profiles. I observed classes in the English Department at both schools and worked with all the teachers (eight at school A and four at school B) in grades 10 and 11 . However, I focused in-depth on the English language classrooms of two teachers teaching grade 10: one classroom was for English home language speakers and the other for speakers of English as additional or second language. I followed these teachers and learners into grade 11 and was thus immersed in the field for two and a half years. While at the schools I acted as a participant observer, helping with teaching and marking of scripts. During this time, I also worked with twelve students who had graduated from these two schools and were in their first year of study in the Faculty of Education at a university. These first-year students had been taught by two of the teachers from each school. Consequently, long-term immersion in both school and university contexts gave me an in-depth understanding of writing practices and discourses in both contexts but more importantly the identityrelated implications of these practices and discourses for students making the transition from the FET Phase to tertiary institutions.

At the same time as I was conducting fieldwork, I began to analyse the NCS (2003) and CAPS (2011) documents to shed light on the theoretical underpinnings. I first analysed the policy discourse and the encapsulated language theories to understand the cultural capital teachers needed to possess to teach writing effectively in the FET Phase. Secondly, I drew on these documents to understand the recommended teacher pedagogy and classroom practices, shedding light on how the policy was interpreted and practised. Thirdly, I analysed the grade 12 (2012) question papers for the EAL subject area. My intention was to explore examiners' understanding of the underpinning theory as evidenced in questions, tasks and texts required at the end of secondary schooling. I was interested in shedding light on how these two factors - national policy and assessment- impact on pedagogy and classroom discourse in the FET Phase. Finally, I analysed ten first year student texts from these two schools in an attempt to explain the kinds of writer identities that emerged. As a result, this study is fundamentally concerned with practice as it is understood, lived or felt in each context.

To engage with my data, I first transcribed and coded my daily classroom discourse fieldnotes, and then I coded these fieldnotes drawing on Bourdieu's concepts of field, habitus and capital to gain insights into the local contextual practices. Secondly, I transcribed and grouped my ethnographic interviews, after this, I grouped these patterns into tentative themes as comparative data and used these themes to initiate follow-up conversations. Here, I drew 
on Bourdieu to illuminate the ways in which national policies constructed perceptions of local practices as well as to foreground positionings enacted in local contexts. Thirdly, I conducted content analysis of the national policies for language education drawing on SFL genre-based theory. This lens was also useful for evaluating the extent to which curriculum, pedagogy and assessment tools inducted learners into the key 'genres of schooling' (such as information report, explanation and argument) necessary for success across the curriculum at school and university. Then, I analysed schoolbased documents, drawing on SFL and Bourdieu to highlight the ways in which routine practices were aligned with national policies, and to open up aspects of the organising practices at school, the differing kinds of cultural capital and the conversion of this capital into other forms of cultural and symbolic capital. Finally, I analysed first-year student scripts, drawing on SFL which allowed for a rigorous linguistic analysis which foregrounded the extent to which writers managed the three metafunctions (ideational, interpersonal and textual) as the basis for coherent, well-structured, genre-appropriate writing.

\section{MUCKING IN THE LIVES' OF OTHERS}

A key feature of the study is the acknowledgement of research as coconstructed and situated in real contexts. Therefore, I included the notion of reflexivity as 'an acknowledgement of the impossibility of remaining 'outside of one's subject matter while conducting research' (Willig, 2005: 10). Through the notion of reflexivity, I hoped in part to open up explorations of how my habitus as a learner and teacher intersected in different ways at the two research sites and my attempts to find my way in them. Consequently, I situated my research with a narrative device that would enable me to map my experience developmentally, to unpack the sometimes messy tensions and frictions that can arise during the research process. Such a narrative sensemaking device allowed me to foreground the ways in which my understanding of the research process altered through an analysis of the repeated acts of identities in which my participants and I engaged both on and off the research 'stage'. As I wrote this dissertation, I was at once director, producer and narrator with the power to decide who will say what and which evidence or props would ultimately be selected to support my argument. In my mind's eye, the research process resembled a performance: schools were my stage, teachers and learners my characters, and when I began writing I was tempted to shout 'Lights, cameraand action!' For this reason, Goffman's (1959) sociological concept of dramaturgy became a crucial component during the conceptualisation and write-up of my study. It enabled me to view the research process as a staged performance, where we were all actors, performing acts of identities. I became aware in particular of the varying roles that I performed when I was front stage, in the field, and how these roles changed when I was backstage, leaving the field.

My situation as participant observer required frequent role shifts, resulting in the need for impression management at various stages of the research process (Goffman, 1959; Flowerdew, 2008). My management of identities during the research process was situated and audience-dependent. For example, during the write-up of my dissertation, I knew the importance of managing an 
identity aligned to disciplinary values, norms and expectations; I wanted my audience to view my identity acts as appropriately aligned to the discourse community. To try and capture these processes of staged performance and impression management at different stages of the research process, my dissertation is divided into acts and scenes, drawing on a theatre story metaphor and paying attention to reflexivity (Davies, 2008; Etherington, 2006). The theatre-story metaphor is thus partly an attempt to find a vehicle for reflexively responding to the impact of the research process on the self and the impact of the self on others. However, and more importantly, it is also a means to help my intended audience understand and share in my field experiences - an aspect often ignored in dissertation write-ups (Wolcott, 2010). For this reason, my dissertation is divided into five acts, each containing some scenes as outlined below.

Act One consists of one scene that has provided the vantage point from which to interpret the study. Then, Act Two consists of two scenes; Scene One reviews the literature concerning Bourdieu and SFL, and Scene Two unpacks the findings of previous studies about this literature. After this, Act Three, two scenes, of which Scene One highlights ethnography as a methodological frame and Scene Two foregrounds the reflexive element of the study. Act Four, includes four scenes that employ both SFL and Bourdieu: first, to analyse policy documents; second, to present the local school contexts; third, to analyse EAL grade 12 question papers; and fourth, to analyse ten first year student scripts. Finally, Act Five concludes the study with a discussion of the findings and recommendations for future research.

\section{LIMITATIONS: DEMARGATING THE LOCATION}

Fieldwork was limited to two feeder schools, investigating a greater number of schools would certainly have generated more data related to writing identities. However, it can be argued that the findings offer a picture of writing practices which is broadly representative of the two kinds of state schools in the Western Cape, and perhaps more widely in South Africa. The focus was the initiation point (Grade ten), an important site for investigating the ways in which writing identities are activated. While it would have been ideal to follow these learners into their final year, this two and a half year ethnography nevertheless enabled me to gain an indepth understanding of how teachers interpreted and implemented the national curriculum.

\section{REFERENGES}

Blommaert, Jan, James Collins, and Stef Slembrouck. 2005. Spaces of multilingualism. In James Collins and Stef Slembrouck (eds). Multilingualism and diasporic populations:

Spatializing practices, institutional processes, and social hierarchies. Special issue of Language E Communication 25 (3): 197-216.

Blommaert, Jan, and Jie Dong. 2010. Ethnographic fieldwork: A beginner's guide. Bristol: Multilingual Matters.

Blommaert, Jan. 2001. Investigating narrative inequality: African asylum seekers' stories in Belgium. Discourse $\mathcal{E}$ Society 12(4): 413-449.

Boughey, Chrissie. 2010. A meta-analysis of teaching and learning at five universities of technology. Pretoria: Council on Higher Education. 
Boughey, Chrissie. 2003. Naming students' problems - an analysis of languagerelated discourses at a South African university. Teaching in Higher Education, 7(3): 295-307.

Bourdieu, Pierre. 1994. Rethinking the state: On the genesis and structure of the bureaucratic field. Sociological Theory, 12: 1-19.

Bourdieu, Pierre. 1990. Language E Symbolic Power. Cambridge, MA: Harvard University Press.

Bourdieu, Pierre, and Jean-Claude Passeron. 1990. Reproduction in education, society and culture. New York: Sage.

Bucholtz, Mary, and Kira Hall. 2005. Identity and interaction: A sociocultural linguistic approach. Discourse studies, 7(4-5): 585-614.

Department of Basic Education. 2011. Curriculum and Assessment Policy Statement (CAPS). Pretoria: Department of Basic Education.

Department of Basic Education. 2003. National Curriculum Statement (NCS). Pretoria: Department of Basic Education.

Davies, Charlotte. 2008. Reflexive ethnography: A guide to researching selves and others. London: Routledge.

Etherington, Kim. 2006. Becoming a reflexive researcher. London and Philadelphia: Jessica Kingsley Publishers.

Flowerdew, John. 2008. Scholarly writers who use English as an additional language: What can Goffman's "stigma" tell us? JEAP, 7: 77-86.

Giddens, Anthony. 1991. Modernity and selfidentity: Self and society in the late modern age, Cambridge, UK: Polity Press
Goffman, Erving. 1959. The presentation of self in everyday life. New York: Doubleday \& Co.

Halliday, Michael. 1985. An introduction to functional grammar. London: Arnold.

Ivanič, Roz. 1998. Writing and identity: The discoursal construction of identity in academic writing. Amsterdam: John Benjamins.

Lea, Mary, and Brian Street. 1998. Student writing in higher education: An academic literacies approach. Studies in Higher Education, 23(2): 157-172.

Lillis, Theresa. 2003. Student writing as "academic literacies": Drawing on Bakhtin to move from critique to design. Language and Education, 17: 192-207.

Norton, Bonny. 2013. Identity and language learning: Extending the conversation. Bristol, UK: Multilingual Matters.

Norton, Bonny, ed. 1997. Language and identity. Special Issue, TESOL Quarterly, $31(3)$.

Pennycook, Alastair. 2007. Global Englishes and transcultural flows. London: Routledge.

Rampton, Ben. 2003. Hegemony, social class, and stylisation. Pragmatics, 13(1): 49-83.

Willig, Carla. 2005. Introducing Qualitative research in Psychology: Adventures in theory and method. Buckingham \& Philadelphia: McGraw \& Hill.

Wolcott, Harry. 2007. The question of intimacy in ethnography. In Geoffrey Walford, (ed) Methodological developments in ethnography. Amsterdam: Elsevier. 